\title{
Comparison of diets for rearing the larvae of Mediterranean fruit fly: nutritional and economic aspects
}

\section{Comparação de dietas para criação de larvas da mosca-do- mediterrâneo: viabilidade nutricional e econômica}

\author{
Daniela Ribeiro da Costa ${ }^{1}$; Suzany Aguiar Leite ${ }^{1}$; Ana Elizabete Lopes Ribeiro ${ }^{2}$; \\ Iara Sordi Joachim-Bravo ${ }^{3}$; Aldenise Alves Moreira ${ }^{4}$; Maria Aparecida Castellani ${ }^{4 *}$
}

\begin{abstract}
The Mediterranean fruit fly Ceratitis capitata (Wiedemann, 1824) (Diptera: Tephritidae) is the main pest of fruit crops worldwide due to its broad distribution, direct damages, and adaptation to different hosts. Developing diets for the rearing fruit flies is essential for integrated management of this pest. Mass rearing of parasitoids, selection of preferred hosts, and mass rearing of genetically modified $C$. capitata strains subsidize methods of biological control, cultural control, and the sterile insect technique (SIT), respectively, depending directly on the mass rearing of the Mediterranean fruit fly. The aim of this study was to assess the effectiveness of artificial diets for rearing C. capitata larvae considering the cost of those most appropriate diets. Nine diets containing different combinations of protein and energy sources (brewer's yeast, yeast extract, pollen, soybean extract, oatmeal, corn meal, and wheat germ) were formulated. The parameters immature development time (hatching), pupal viability (emerged adults), size and weight of pupae, and adult size (wing length) were assessed. The experiments were conducted in the laboratory under controlled conditions of temperature $\left(26 \pm 1^{\circ} \mathrm{C}\right)$ and relative humidity $(70 \% \pm 10 \%)$. Statistical analysis was performed by using ANOVA with the Tukey's test for comparison of means. Diets based on oatmeal and soybean extract, both added with brewer's yeast, yeast extract, or pollen satisfactorily meet the nutritional requirements of $C$. capitata. Moreover, diets enriched with brewer's yeast or yeast extract presented the lowest costs; therefore, they could be used in a continuous mass-scale rearing of $C$. capitata. Diets based on corn meal and soybean extract, both associated with brewer's yeast, yeast extract, or pollen are more economical, but they should not be used for rearing $C$. capitata because they decrease the percentage of hatching and extend life cycle. Diets based on wheat germ and oatmeal, both added with brewer's yeast, yeast extract, or pollen are not adequate for rearing C. capitata.
\end{abstract}

Key words: Ceratitis capitata. Mass rearing. Production cost. Protein.

\section{Resumo}

A mosca-do-mediterrâneo Ceratitis capitata (Wiedemann, 1824) (Diptera: Tephritidae) é a principal praga da fruticultura mundial pela sua ampla distribuição, danos diretos e adaptação a diversos hospedeiros. O desenvolvimento de dietas para criação de moscas-das-frutas é fundamental para o

${ }^{1}$ Eng $^{\text {as }}$ Agr $^{\text {as }}$, Discentes de Doutorado, Programa de Pós-Graduação em Agronomia, Universidade Estadual do Sudoeste da Bahia, UESB, Vitória da Conquista, BA, Brasil.E-mail: danielaribeirodacosta@yahoo.com.br; suzanyleite@yahoo.com.br

${ }^{2}$ Eng $^{\mathrm{a}}$ Agr $^{\mathrm{a}}$, Prof ${ }^{\mathrm{a}}$ Dr $^{\mathrm{a}}$, Centro Multidisciplinar, Universidade Federal do Oeste da Bahia, UFOB, Barra, BA, Brasil. E-mail: ana. lopes@ufob.edu.br

${ }^{3}$ Bióloga, Prof ${ }^{a}$ Dra $^{\text {a }}$, Instituto de Biologia, Universidade Federal da Bahia, UFBA, Salvador, BA, Brasil. E-mail: ibravo@ufba.br

${ }^{4}$ Eng $^{\text {as }}$ Agr $^{\text {as }}$, Prof ${ }^{\text {as }}$ Dr $^{\text {as }}$, Departamento de Fitotecnia e Zootecnia, UESB, Vitória da Conquista, BA, Brasil. E-mail: aldenise. moreira@gmail.com; castellani@uesb.edu.br

* Author for correspondence 
manejo integrado dessa praga. Criação massal de parasitoides, seleção de hospedeiros preferenciais e criação massal de linhagens de $C$. capitata geneticamente modificadas subsidiam métodos de controle biológico, cultural e a técnica do inseto estéril, respectivamente, dependendo diretamente da criação massal da mosca-do-mediterrâneo. O objetivo do trabalho foi avaliar a eficácia de dietas artificiais para criação de larvas de C. capitata, levando-se em conta o custo daquelas mais adequadas. Nove dietas contendo diferentes combinações de fontes proteicas e energéticas (levedo de cerveja, extrato de levedura, pólen, extrato de soja, aveia, fubá de milho e gérmen de trigo) foram formuladas. Os seguintes parâmetros foram avaliados: tempo de desenvolvimento dos imaturos (eclosão-emergência), viabilidade pupal (adultos emergidos), tamanho e peso das pupas e tamanho dos adultos (comprimento da asa). Os experimentos foram conduzidos em laboratório em condições controladas de temperatura $\left(26 \pm 1{ }^{\circ} \mathrm{C}\right)$ e umidade relativa $(70 \% \pm 10 \%)$. Para a análise estatística utilizou-se ANOVA com teste Tukey para comparação das médias. As dietas à base de aveia e extrato de soja, acrescidas de levedo de cerveja ou extrato de levedura ou pólen, atendem satisfatoriamente as exigências nutricionais de C. capitata, sendo aquelas acrescidas de levedo de cerveja ou extrato de levedura de menores custos, podendo ser utilizadas em criações contínuas e em escala massal de C. capitata. Dietas compostas por fubá de milho e extrato de soja, acrescidas de levedo de cerveja ou extrato de levedura ou pólen, apesar de mais econômicas não devem ser utilizadas para criação de C. capitata, pois diminuem a porcentagem de emergência e prolongam o ciclo de vida. Dietas compostas por gérmen de trigo e aveia, acrescidas de levedo de cerveja ou extrato de levedura ou pólen não são adequadas para criação de C. capitata.

Palavras-chave: Ceratitis capitata. Criação massal. Custo de produção. Proteína.

\section{Introduction}

The Mediterranean fruit fly Ceratitis capitata (Wiedemann, 1824) (Diptera: Tephritidae) is one of the main pest of fruit crops worldwide, presenting a wide geographical distribution and great diversity of hosts (SILVA, 2000). The most modern technique for its control is the sterile insect technique (SIT), which consists of releasing sterile males of fruit flies in the field to compete with those wild for females aiming at progressively decreasing their population (DIAS; GARCIA, 2014). The development of viable artificial diets for mass rearing of insects to be used in this technique, both from a nutritional and economic point of view, is essential for its effective implantation and maintenance (HERNÁNDEZ et al., 2010).

Several diets have been used in the large-scale commercial production of fruit flies worldwide (ALUJA et al., 2001). In a mass rearing for sterile insects, the use of diets to ensure the production of males with standardized sizes and larger than those found in nature are relevant to the success of this technique since male size is an important factor during copulation (ANJOS-DUARTE et al., 2011; AQUINO; JOACHIM-BRAVO, 2014). A good nutrition in the larval phase is necessary for a proper development, affecting survival and adult size (CRESONI-PEREIRA; ZUCOLOTO, 2009).

In nature, the host used as food in the larval phase (ZANARDI et al., 2011) affects biological parameters such as immature development time, pupal and adult weight and viability, pre-oviposition period, and daily and total fecundity of C. capitata. In laboratory tests, adult females and males of $C$. capitata fed in the larval phase diets with a higher amount of protein are much larger when compared to adults reared with a smaller amount of this nutrient (ANJOS-DUARTE et al., 2011; SILVA NETO et al., 2012). Thus, choosing an adequate protein source for a diet formulation for fruit flies is a key factor for the success of a mass rearing.

Larvae and adults of holometabolous insects such as fruit flies have, in general, different food habits and may present distinct nutritional and diet physical aspect requirements such as texture and water content (JOACHIM-BRAVO, 2009). Thus, not always a diet formulated for one stage is ideal for another, which may affect rearing costs. Additionally, some diet ingredients may be costly; therefore, even if nutritionally viable, they 
should be replaced for the economic feasibility of rearing colonies, if minimum acceptable biological parameters are kept (FAO/IAEA/USDA, 2003). Silva Neto et al. (2012), for example, working with diets for adults of $C$. capitata, obtained better results for biological parameters of fruit flies when using yeast extracts produced in Brazil in substitution of a most costly imported hydrolyzed protein.

Different artificial diets for rearing larvae and adults of $C$. capitata have been developed to meet both nutritional requirements and the low production cost (JOACHIM-BRAVO et al., 2006; NESTEL; NEMNY-LAVY, 2008; SILVA NETO et al., 2012). The diets most commonly used for rearing C. capitata larvae are based on yeast or soybean extract as protein sources (CHAN et al., 1990), as well as soybean meal or oatmeal, which are also rich carbohydrate sources (JOACHIM-BRAVO et al., 2006). Pollen is considered an essential protein source for larvae and adults of bees and other insects (ZERBO et al., 2001), also presenting lipids, ashes, and carotenoids (ALMEIDA-MURADIAN et al., 2005). Despite the high nutritional value of pollen and other nutritional sources such as yeast extract, little is known about their effects in rearing Tephritidae insects.

In order to obtain an economically and nutritionally viable diet, this study aimed to assess the effectiveness of several combinations of low cost and easy-to-obtain energy and protein sources in rearing Mediterranean fruit flies in the larval phase.

\section{Material and Methods}

The experiment was carried out under laboratory conditions in a completely randomized design with nine treatments (diets) (Table 1) and three replications with each plot consisting of 20 Petri dishes containing one egg of $C$. capitata, totaling 60 dishes per treatment.

Table 1. Ingredients and respective compositions of the studied diets (g) for larvae of Ceratitis capitata (Diptera: Tephritidae).

\begin{tabular}{cccccccccc}
\hline \multirow{2}{*}{ Ingredient } & \multicolumn{10}{c}{ Diet composition (g) } \\
\cline { 2 - 10 } & $\mathrm{T} 1$ & $\mathrm{~T} 2$ & $\mathrm{~T} 3$ & $\mathrm{~T} 4$ & $\mathrm{~T} 5$ & $\mathrm{~T} 6$ & $\mathrm{~T} 7$ & $\mathrm{~T} 8$ & $\mathrm{~T} 9$ \\
\hline Brewer's yeast & 43 & - & - & 43 & - & - & 43 & - & - \\
Yeast extract & - & 43 & - & - & 43 & - & - & 43 & - \\
Pollen & - & - & 43 & - & - & 43 & - & - & 43 \\
Soybean extract & 163 & 163 & 163 & - & - & - & 163 & 163 & 163 \\
Oatmeal & 163 & 163 & 163 & 163 & 163 & 163 & - & - & - \\
Corn meal & - & - & - & 163 & 163 & 163 & - & - & - \\
Wheat germ & - & - & - & - & - & - & 163 & 163 & 163 \\
Sugar & 41.5 & 41.5 & 41.5 & 41.5 & 41.5 & 41.5 & 41.5 & 41.5 & 41.5 \\
Sodium benzoate & 1.25 & 1.25 & 1.25 & 1.25 & 1.25 & 1.25 & 1.25 & 1.25 & 1.25 \\
Nipagin & 3.25 & 3.25 & 3.25 & 3.25 & 3.25 & 3.25 & 3.25 & 3.25 & 3.25 \\
Citric acid & 3.5 & 3.5 & 3.5 & 3.5 & 3.5 & 3.5 & 3.5 & 3.5 & 3.5 \\
Water (mL) & 500 & 500 & 500 & 500 & 500 & 500 & 500 & 500 & 500 \\
\hline
\end{tabular}

Diets T1, T2, and T3 were prepared based on soybean extract and oatmeal with brewer's yeast, yeast extract, and pollen, respectively. Diet T1 (with brewer's yeast) was considered as a standard since it has been commonly used in fruit fly diets.
Bionis $^{\circledR}$ yeast extract is successfully used in adult diets of fruit flies and present a higher amount of protein. Pollen also has an energy source although containing proteins. Diets T4, T5, and T6 were formulated with corn meal and oatmeal (two energy 
sources) and the addition of brewer's yeast, yeast extract, and pollen, respectively. Finally, diets T7, $\mathrm{T} 8$, and T9 were based on soybean extract and wheat germ (protein and energy sources) with brewer's yeast, yeast extract, and pollen, respectively. All diet ingredients presented a variation in the amount of carbohydrates and proteins (Table 2).

Table 2. Nutritional information on ingredients used in diets for larvae of Ceratitis capitata (Diptera: Tephritidae).

\begin{tabular}{cccccc}
\hline \multirow{2}{*}{ Ingredient $(100 \mathrm{~g})$} & \multicolumn{5}{c}{ Nutritional information } \\
\cline { 2 - 5 } & Carbohydrate $(\mathrm{g})$ & Protein $(\mathrm{g})$ & Total fat $(\mathrm{g})$ & Calcium $(\mathrm{mg})$ & Iron $(\mathrm{mg})$ \\
\hline Brewer's yeast & 32.0 & 46.7 & 0.0 & 100.0 & 20.0 \\
Yeast extract & 17.0 & 65.0 & 0.3 & - & - \\
Pollen & 2.7 & 2.5 & 0.7 & - & - \\
Soybean extract & 26.0 & 43.3 & 21.0 & - & 5.0 \\
Oatmeal & 65.0 & 10.0 & 10.0 & 10.0 & 2.5 \\
Corn meal & 97.5 & 7.5 & 2.5 & - & 2.5 \\
Wheat germ & 52.0 & 23.0 & 10.0 & - & - \\
\hline
\end{tabular}

Diets were prepared by mixing all dry ingredients, except for Nipagin, which was diluted in alcohol, and sodium benzoate and citric acid, which was diluted in $250 \mathrm{~mL}$ of water. The remaining water $(250 \mathrm{~mL})$ was gradually added until a consistent and homogeneous mixture was obtained. Subsequently, $5 \mathrm{~g}$ of these diets were distributed in Petri dishes, being identified, and maintained under refrigeration.

Eggs of $C$. capitata were collected from laboratory rearing and after asepsis, distributed in Petri dishes containing de different diets. Subsequently, diets were placed in plastic trays, covered with wood paper, and conditioned in a climatized room at a temperature of $26 \pm 1{ }^{\circ} \mathrm{C}$ and relative humidity of $70 \pm 10 \%$.

The assessments were performed daily from the larval hatching to adult emergence without changing the diets. Pupal mass was obtained of pupae with 24 hours by using a precision scale and pupa measurements (length and diameter) using a stereomicroscope (ZART et al., 2010). The pupae were individualized and placed in Petri dishes containing a thin layer of vermiculite. After emergence, the adults were fixed in $70 \%$ alcohol for measuring the wings. Adult size (estimated by the measurement of the distance between the nervures
$\mathrm{R}_{4+5}$ and cu-m of the right wing of females) was obtained by using a stereomicroscope equipped with a micrometric eyepiece with $0.5 \mathrm{~mm}$ conversion in a 20 -fold increase. The viability and pupal size (mass, length, and diameter), duration of the period from egg to adult and adult size (wing measurement) were assessed. The data were submitted to analysis of variance and the means compared by the Tukey's test at $5 \%$ probability using the programs SISVAR and R Core Team (2015).

A cost analysis was carried out in September 2016, considering the price of ingredients in the diets with satisfactory results (soybean extract and oatmeal from Advir Produtos Naturais Integrais ${ }^{\mathbb{B}}$ and corn meal from Bahia $^{\circledR}$ ), in addition to the brewer's yeast from Advir Produtos Naturais Integrais ${ }^{\circledR}$, yeast extract from Bionis ${ }^{\circledR}$, and pollen from Apis Jordans.

\section{Results and Discussion}

Pupal viability and the total cycle of $C$. capitata varied significantly between treatments. Diets T1 (considered as the standard diet and presenting brewer's yeast, soybean extract, and oatmeal), T2 (yeast extract, soybean extract, and oatmeal), and 
T3 (pollen, soybean extract, and oatmeal) presented emergence percentages of 73,83 , and $60 \%$, respectively. These three diets presented a lower development time (18, 19 and 19 days, respectively), being equal to each other and significantly different from diets T4, T5, and T6 (Table 3). Diets T4, T5, and T6 were inadequate as they presented a pupal viability of $6 \%$ (T6) to $21 \%$ (T4) and cycle length of 20 (T4) to 23 days (T6). Diets T7, T8, and T9 presented the worst performances, with a total absence of pupal formation. Thus, variables related to pupal and adult size were obtained only for diets T1 to T6.

Table 3. Pupal viability (\%) and the total cycle of Ceratitis capitata (Diptera: Tephritidae) according to diets offered to the larvae.

\begin{tabular}{lcc}
\hline \multicolumn{1}{c}{ Diet } & $\begin{array}{c}\text { Pupal viability } \\
(\%)\end{array}$ & $\begin{array}{c}\text { Immature development } \\
(\text { days)* }\end{array}$ \\
\hline T1 (standard diet)** & 73 & $18 \mathrm{a}$ \\
T2 (soybean extract + oatmeal + yeast extract)** & 83 & $19 \mathrm{a}$ \\
T3 (soybean extract + oatmeal + pollen)** & 60 & $19 \mathrm{a}$ \\
T4 (corn meal + oatmeal + brewer's yeast)** & 21 & $20 \mathrm{~b}$ \\
T5 (corn meal + oatmeal + yeast extract)** & 13 & $21 \mathrm{~b}$ \\
T6 (corn meal + oatmeal + pollen)** & 06 & $23 \mathrm{c}$ \\
T7 (soybean extract + wheat germ + brewer's yeast)** & - & - \\
T8 (soybean extract + wheat germ + yeast extract)** & - & - \\
T9 (soybean extract + wheat germ + pollen)** & - & - \\
\hline
\end{tabular}

Means followed by the same letter do not differ from each other $(\mathrm{p}>0.05)$ by the Tukey's test.

* Means transformed into $\sqrt{x+1}$.

** Ingredients with sugar, sodium benzoate, Nipagin, citric acid, and water.

Diets based on oatmeal and soybean extract, with the addition of brewer's yeast (T1), yeast extract (T2), and pollen (T3), produced larger pupae, not differing from each other. The pupal size was significantly higher in the diet $\mathrm{T} 1$ when compared to the diets T4, T5, and T6, which resulted in smaller pupae (Figure 1A). Pupal diameter varied according to the diets. In this sense, diet T6 provided pupae of smaller diameter, with no significant differences between diets (Figure 1B). No effect of diet on the pupal mass (Figure 1C) was observed. As expected, diet T6, which provided pupae of smaller length and diameter, also resulted in significantly smaller fruit flies (Figure 1D). Overall, diets containing oatmeal plus corn meal with addition brewer's yeast, yeast extract, or pollen should not be used in mass rearing of $C$. capitata since they reduce pupal and adult size and hence adult quality regarding the ecological and reproductive aspects.
Diet T1 (standard) allowed adult development in a shorter time (18 days), greater pupal viability (73\%), and greater adult size (average of $2.89 \mathrm{~mm}$ ). These results are in accordance with those obtained by Joachim-Bravo et al. (2006), who obtained good results in rearing $C$. capitata larvae from a diet containing sucrose and the same ingredients of diet T1 of our study. These authors found immature development in a shorter time (19 days) and higher emergence percentage (96\%) and adult size (average of $2.87 \mathrm{~mm}$ ). Artificial diets must meet insect needs with nutrients required for their development, with protein and energy sources such as carbohydrates. The oatmeal and soybean extract-based diet, with the addition of brewer's yeast (T1), presented good results maybe because it presented adequate physical characteristics and provided an appropriate balance between proteins (soybean extract and brewer's yeast) and carbohydrates (oatmeal) required for the development of $C$. capitata larvae. 
Figure 1. Pupal length (A), pupal diameter (B), pupal mass (C), and adult size (D) of Ceratitis capitata (Diptera: Tephritidae) as a function of diets offered to the larvae.

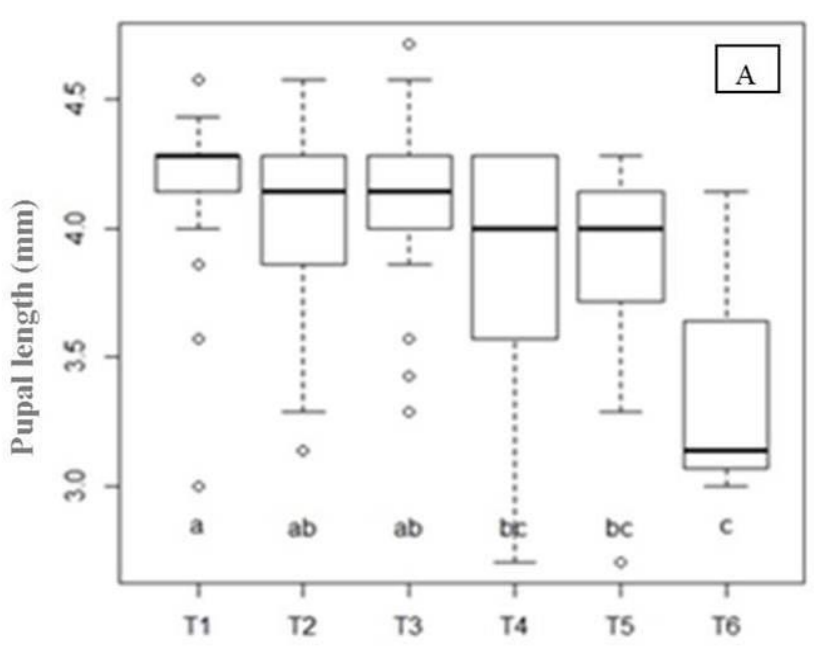

Diets

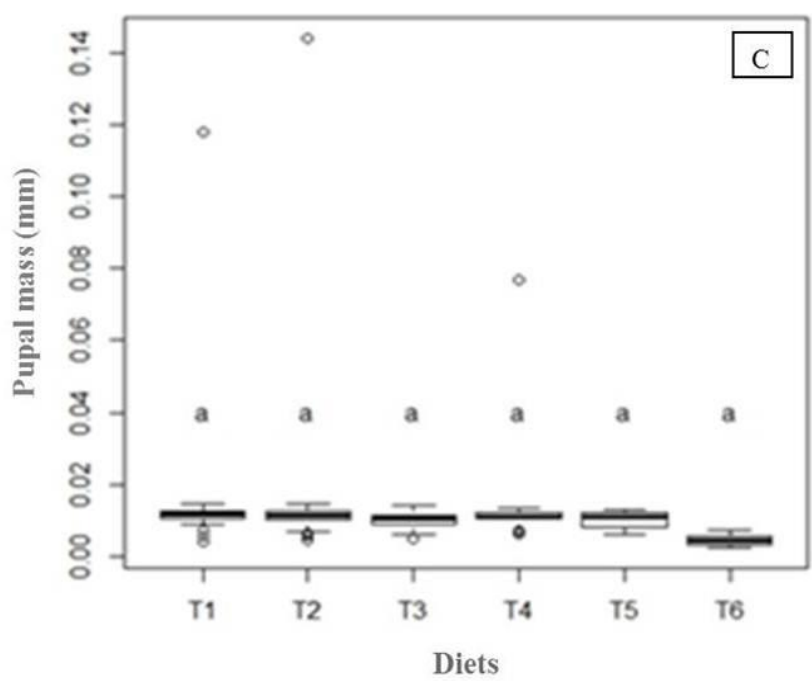

Diets T4, T5, and T6 provided a life cycle extension of $C$. capitata and reduction of adult emergence, reaching indices less than $50 \%$. When the nutritional needs of insects are not met by the diet, problems of performance, increased development time, and adult size may occur (CRESONIPEREIRA; ZUCOLOTO, 2009). Problems such as dehydration over the days and hardening were observed in the corn meal-based diet. These aspects may have hampered the movement and feeding of larvae, as well as gallery formation since they were always found on diet surface, leading to a higher
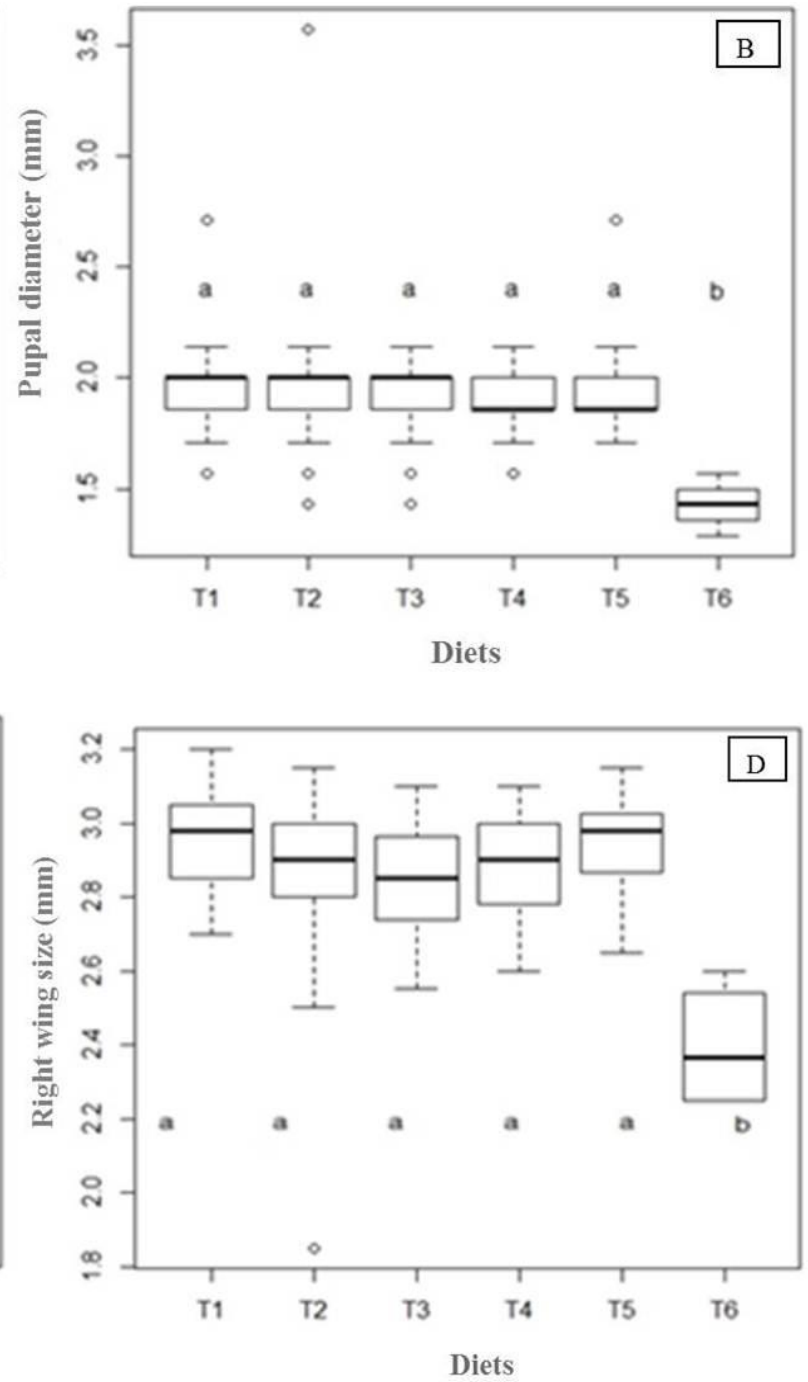

energy expenditure to deepen. Such difficulties were observed during the assessments. This may justify the premature death of larvae and the lower emergence of adults in diets containing corn meal as a source of carbohydrate. According to PlacidoSilva et al. (2005), foods low in protein, such as corn meal and oatmeal, reduce the larval size and, consequently, puparium weight, in addition to decreasing emergence percentage and increasing development time (CANGUSSU; ZUCOLOTO, 1997). Joachim-Bravo et al. (2006) used cooked corn meal on a diet for rearing C. capitata larvae 
and found immatures with longer life cycles and emergence below 50\%. Despite this low emergence percentage and life cycle extension, aspects of pupa and adult size were not affected by diets $\mathrm{T} 4$ and $\mathrm{T} 5$, which presented values statistically equal to those obtained for diets T1, T2, and T3.

Diets with wheat germ and soybean extract, both added with brewer's yeast (T7), yeast extract (T8), or pollen (T9) allowed larva hatching, reaching only the phase L1 and then dying. These results are in accordance with studies developed by Salles (1992) with a diet based on sugar, brewer's yeast, and wheat germ for larvae of Anastrepha fraterculus (Wiedemann, 1830). The author observed problems related to egg viability and larval establishment in the artificial diet. Although the wheat germ-based diet has not been successful in our study, Efrom (2009) and Jaldo et al. (2001), also using a wheat germ-based diet, observed satisfactory results for rearing larvae of $A$. fraterculus in the laboratory. Likewise, Nunes et al. (2013) highlighted the suitability of diets with brewer's yeast and wheat germ for the rearing larvae of $A$. fraterculus. Walder et al. (2014) obtained satisfactory results with a large-scale production of diets with wheat germ for $A$. fraterculus. However, a drastic decrease in larval viability occurred in some generations due to a different batch or supplier, which would probably be contaminated with toxic substances. Moreover, when rearing the mutant strain Vienna $8-t s l$, Damasceno (2013) observed that the use of wheat germ and wheat flour in the diet of $C$. capitata larvae resulted in a lower number of pupae, although they were the heaviest.

To produce $1 \mathrm{~kg}$ of diets T1, T2, and T3, $86 \mathrm{~g}$ of brewer's yeast or yeast extract or pollen and $326 \mathrm{~g}$ of oatmeal and soybean extract are required. For diets T4, T5, and T6, $86 \mathrm{~g}$ of brewer's yeast or yeast extract or pollen and $326 \mathrm{~g}$ of oatmeal and corn meal are required. In this sense, the lowest production costs were observed for diets T4 and T5. Diet T4 with brewer's yeast has a lower cost when compared to diets T5 and T6, with a value of R\$ 6.52 per $\mathrm{kg}$ of diet (Table 4). Diet T5 with Bionis ${ }^{\circledR}$ yeast extract has a cost of R\$ 7.08 and diet T6 with pollen has a cost of $\mathrm{R} \$ 13.32$. However, in spite of being economical, these diets (T4, T5, and T6) should not be used for rearing $C$. capitata since they decrease the emergence percentage and extend the life cycle. Diets T1, T2, and T3 presented costs of $\mathrm{R} \$ 11.32, \mathrm{R} \$ 11.88$, and R\$ 18.12, respectively, per $\mathrm{kg}$ of diet (Table 4).

Table 4. Diets for larvae of Ceratitis capitata (Diptera: Tephritidae) as a function of ingredients and respective costs.

\begin{tabular}{cccc}
\hline Diet & Ingredient & Cost $(\mathrm{R} \$)$ & Total $(\mathrm{R} \$)$ \\
\hline T1 & Soybean extract + oatmeal + brewer's yeast & $7.00+3.59+0.73$ & 11.32 \\
T2 & Soybean extract + oatmeal + yeast extract & $7.00+3.59+1.29$ & 11.88 \\
T3 & Soybean extract + oatmeal + pollen & $7.00+3.59+7.53$ & 18.12 \\
T4 & Corn meal + oatmeal + brewer's yeast & $2.20+3.59+0.73$ & 6.52 \\
T5 & Corn meal + oatmeal + yeast extract & $2.20+3.59+1.29$ & 7.08 \\
T6 & Corn meal + oatmeal + pollen & $2.20+3.59+7.53$ & 13.32 \\
\hline
\end{tabular}

Thus, in a continuous mass rearing, the use of diets T1 (standard) and T2 (soybean extract + oatmeal + Bionis $^{\circledR}$ yeast extract) for rearing larvae of $C$. capitata is the most advantageous from a biological and economic point of view. The effectiveness of yeast extract-based diets $\left(\right.$ Bionis $\left.^{\circledR}\right)$ for adults of C. capitata has also been proven in other studies (SILVA-NETO et al., 2012). Therefore, in a large bio-factory, the ingredient yeast extract could be used for larval and adult nutrition, optimizing costs. 


\section{Conclusions}

Diets based on oatmeal and soybean extract, both added with brewer's yeast, yeast extract, or pollen meet the nutritional requirements of $C$. capitata satisfactorily. Moreover, diets enriched with brewer's yeast or yeast extract presented the lowest costs; therefore, they can be used in a continuous mass-scale rearing of this insect.

Although more economical, diets based on corn meal and soybean extract, both added with brewer's yeast, yeast extract, or pollen, should not be used for the rearing of $C$. capitata. These diets decrease the emergence percentage and extend the life cycle.

Likewise, diets based on wheat germ and oatmeal, both added with brewer's yeast, yeast extract, or pollen, are not suitable for the rearing of C. capitata.

\section{References}

ALMEIDA-MURADIAN, L. B.; PAMPLONA, L. C.; COIMBRA, S.; BARTH, O. M. Chemical composition and botanical evaluation of dried bee pollen pellets. Journal of Food Composition and Analysis, San Diego, v. 18, n. 6, p. 105-111, 2005.

ALUJA, M.; JÁCOME, I.; MACIAS-ORDÓÑEZ, R. Effect of adult nutrition on male sexual performance in four tropical fruit fly species of the genus Anastrepha (Diptera: Tephritidae). Journal of Insect Behavior, New York, v. 14, n. 1, p. 759-775, 2001.

ANJOS-DUARTE, C. S.; COSTA, A. M.; JOACHIMBRAVO, I. S. Influence of female age on variation of mate choice behavior in mediterranean fruit fly (Diptera: Tephritidae). Journal of Insect Behavior, New York, v. 24, n. 1, p. 11-21, 2011.

AQUINO, J. C.; JOACHIM-BRAVO, I. S. Relevance of male size to female mate choice in Ceratitis capitata (Diptera: Tephritidae): investigations with wild and laboratory-reared flies. Journal of Insect Behavior, New York, v. 27, n. 2, p. 162-176, 2014.

CANGUSSU, J. A.; ZUCOLOTO, F. S. Effect of protein sources on fecundity, food acceptance and sexual choice by Ceratitis capitata (Diptera, Tephritidae). Revista Brasileira de Biologia, São Carlos, v. 5, n. 4, p. 611-618, 1997.
CHAN, H. T.; HANSEN, J. D.; TAM, S. Y. T. Larval diets from different protein sources for Mediterranean fruit flies (Diptera: Tephritidae). Journal of Economic Entomology, Lanham, v. 83, n. 5, p. 1954-1958, 1990.

CRESONI-PEREIRA, C.; ZUCOLOTO, F. S. Moscasdas-frutas (Diptera). In: PANIZZI, A. R.; PARRA, J. R. P. (Ed.). Bioecologia e nutrição de insetos: base para o manejo integrado de pragas. Brasília: Embrapa Informação Tecnológica, 2009. cap. 18, p. 733-766.

DAMASCENO, I. C. Influência da composição da dieta larval e da radiação X na qualidade de Ceratitis capitata Wiedemann, 1824 (Diptera: Tephritidae) produzida em criação massal. 2013. Dissertação (Mestrado Profissional em Defesa Agropecuária) - Universidade Federal do Recôncavo da Bahia. Cruz das Almas, Bahia.

DIAS, N. P.; GARCIA, F. R. M. Fundamentos da técnica do inseto estéril (TIE) para o controle de moscas-dasfrutas (Diptera, Tephritidae). Biológico, São Paulo, v. 76, n. 1, p. 58-62, 2014.

EFROM, C. F. S. Criação de Anastrepha fraterculus (Wied.) (Diptera: Tephritidae) em dieta artificial e avaliação de produtos fitossanitários utilizados no sistema orgânico de produção sobre esta espécie e insetos benéficos. 2009. Tese (Doutorado) - Programa de Pós-Graduação em Fitotecnia. Faculdade de Agronomia, Universidade Federal do Rio Grande do Sul, Porto Alegre.

FOOD AND AGRICULTURE ORGANIZATION/ INTERNATIONAL ATOMIC ENERGY AGENCY/ UNIDET STATES DEPARTMENT AGRICULTURE - FAO/IAEA/USDA. Manual for product for quality control and shipping procedures for sterile mass-reared tephritid fruit flies, version 5.0. International Atomic energy Agency, Vienna, Austria, 2003. 85 p.

HERNÁNDEZ, E.; RIVERA, J. P.; OROZCO-DAVILA, D.; SALVADOR, M.; TOLEDO, J. An artificial larval diet for rearing of Anastrepha striata (Diptera: Tephritidae). Florida Entomologist, Gainesville, v. 93, n. 2, p. 167174, 2010.

JALDO, H. E.; GRAMAJO, M.C.; WILLINK, E. Mass rearing of Anastrepha fraterculus (Diptera: Tephritidae) a preliminary strategy. Florida Entomologist, Gainesville, v. 84, n. 4, p. 716-718, 2001.

JOACHIM-BRAVO, I. S. Aspectos básicos de nutrição e dietas artificiais para criação de moscas-das-frutas. In: MALAVASI, A. (Ed.). Biologia, monitoramento e controle de moscas-das-frutas. V Curso internacional de capacitação em moscas-das-frutas. Juazeiro: Moscamed Brasil, p. 21-23, 2009. 
JOACHIM-BRAVO, I. S.; VIEIRA, E. N. F.; RORIZ, A. K. P.; JACOBINA, L. L. Influência de diferentes dietas em parâmetros biológicos e comportamentais de Ceratitis capitata (Diptera: Tephritidae). Sitientibus Série Ciências Biológicas, Feira de Santana, v. 6, n. 4, p. 237-242. 2006.

NESTEL, D.; NEMNY-LAVY, E. Nutrient balance in medly, Ceratitis capitata, larval diets affects the ability of the developing insect to incorporate lipid and protein reserves. Entomologia Experimental et Applicata, Dordrecht, v. 126, n. 1, p. 53- 60, 2008.

NUNES, A. M.; COSTA, K. Z.; FAGGIONI, K. M.; COSTA, M. L. Z.; GONÇALVES, R. S.; WALDER, J. M. M.; GARCIA, M. S.; E NAVA, D. E. Dietas artificiais para a criação de larvas e adultos da mosca-das-frutas sulamericana. Pesquisa Agropecuária Brasileira, Brasília, v. 48, n. 10, p. 1309-1314, 2013.

PLÁCIDO-SILVA, M. C.; ZUCOLOTO, F. S.; JOACHIM-BRAVO, I. S. Influence of protein on feeding behavior of ceratitis capitata wiedemann (Diptera: Tephritidae): comparison between immature males and females. Neotropical Entomology, Londrina, v. 34, n. 4, p. 539-545, 2005.

R DEVELOPMENT CORE TEAM. R: a language and environment for statistical computing. Vienna. R Foundation for Statistical Computing, 2015. Available at: $<$ http://www.R-project.org/>. Accessed at: 02 mar. 2015.

SALLES, L. A. B. Metodologia de criação de Anastrepha fraterculus (Wied., 1830) (Diptera: Tephritidae) em dieta artificial em laboratório. Anais da Sociedade Entomologica, Londrina, v. 21, n. 3, p. 479-486, 1992.
SILVA NETO, A. M. da; SANTOS, T. R. de O.; DIAS, V. S.; JOACHIM-BRAVO, I. S.; BENEVIDES, L. de J.; BENEVIDES, C. M. de J.; SILVA, M. V. L.; SANTOS, D. C. C. dos; VIRGÍNIO, J.; OLIVEIRA, G. B.; WALDER, J. M. M.; PARANHOS, B. A. J.; NASCIMENTO, A. S. do. Mass-rearing of Mediterranean fruit fly using low-cost yeast products produced in Brazil. Scientia Agricola, Piracicaba, v. 69, n. 6, p. 364-369, 2012.

SILVA, J. G. Estudos moleculares. In: MALAVASI, A.; ZUCCHI, R.A. (Ed.). Moscas-das-frutas de importância econômica no Brasil. Conhecimento básico e aplicado. Ribeirão Preto: Holos, 2000. p. 29-39.

WALDER, J. M. M.; MORELLI, R.; COSTA, K. Z.; FAGGIONI, K. M.; SANCHES, P. A.; PARANHOS, B. A. J.; BENTO, J. M. S.; COSTA, M. L. Z. Large scale artificial rearing of Anastrepha sp.1 aff. fraterculus (Diptera: Tephritidae) in Brazil. Scientia Agricola, Piracicaba, v. 71, n. 4, p. 281-286, 2014.

ZANARDI, O. Z.; NAVA, D. E.; BOTTON, M.; GRÜTZMACHER, A. D.; MACHOTA JUNIOR, R.; BISOGNIN, M. Desenvolvimento e reprodução da mosca-do-mediterrâneo em caquizeiro, macieira, pessegueiro e videira. Pesquisa Agropecuária Brasileira, Brasília, v. 46, n. 7, p. 682-688. 2011.

ZART, M.; FERNANDES, O. A.; BOTTON, M. Biology and life table of the South American fruit fly Anastrepha fraterculus on grape. Bulletin of Insectology, Bologna, v. 63, n. 2, p. 237-242. 2010.

ZERBO, A. C.; MORAES, R. L. M. S.; BROCHETTOBRAGA, M. R. Protein requirements in larvae and adults of Scaptotrigona postica (Hymenoptera: Apidia, Meliponinae): midgut proteolytic activity and pollen digestion. Comparative Biochemistry and Physiology, Oxford, v. 129, n. 1, p. 139-147, 2001. 
